\title{
PERTANGGUNGJAWABAN HUKUM PEJABAT PEMBUAT KOMITMEN (PPK) DALAM PENGADAAN BARANG/JASA PEMERINTAH
}

\author{
Naony Fenti Istiqlallia, Raissa Ardelia, Pramudya Ramadhanti \\ Magister Kenotariatan Universitas Airlangga \\ e-mail: fnaony@gmail.com, raissaardelia@ymail.com,pramudyaramadhanti@yahoo.com
}

\begin{abstract}
ABSTRAK
Ketidakjelasan hukum Pejabat Pembuat Komitmen (PPK) terkait pertanggungjawaban hukum atas penyimpangan dalam pengadaan barang/jasa pemerintah, yang menimbulkan ketidakadilan hukum berdasarkan Peraturan Pemerintah tentang Pengadaan Barang/Jasa, terlihat bahwa dalam proses pengadaan barang/jasa, tidak hanya melibatkan PPK saja namun juga ada pihak lain yang berperan dalam pengadaan barang/jasa yang saling berkaitan yaitu PA dan KPA. Jurnal ini akan membahas mengenai kedudukan KPA dalam kontrak pengadaan barang/jasa; tanggung jawab pribadi PPK; batas tanggung jawab PPK. Penelitian ini adalah penelitian normatif. Hasil dari penelitian ini kedudukan PPK dalam kontrak pengadaan barang/ jasa pemerintah dimulai dari menetapkan rancangan kontrak, mengendalikan Kontrak dan penyelesaian Kontrak. Sehingga PPK turut bertanggungjawab terhadap tuntutan jika terjadi kesalahan. Tanggung jawab pribadi PPK dalam pengadaan barang/jasa pemerintah adalah tanggung jawab pribadi yang timbul atas tindakan maladministrasi PPK dalam penggunaan wewenang sebagai pejabat pelaksana dan tindakan maladministrasi tersebut melahirkan tanggung jawab pidana. Sedangkan tanggung jawab jabatan PPK dalam pengadaan barang/jasa pemerintah adalah tanggung jawab keabsahan (legalitas) penggunaan wewenang dalam pengadaan oleh PPK yang bertumpu pada wewenang, prosedur dan substansi, dan melahirkan tanggung gugat pemerintah/negara.
\end{abstract}

Kata Kunci: Tanggung Jawab; Pejabat Pembuat Komitmen; Penyimpangan Pengadaan Barang/Jasa

\section{ABSTRACT}

Legal ambiguity of Commitment Making Officials (PPK) related to legal responsibility for irregularities in the procurement of government goods/services, which causes legal injustice based on Government Regulations on the Procurement of Goods/Services, it is seen that in the process of procuring goods/services, it does not only involve PPK but also exists other parties that play a role in the procurement of goods/services that are interrelated, namely PA and KPA. This journal will discuss the position of KPA in the goods/services procurement contract; PPK personal responsibility; KDP's limit of responsibility. This research is a normative study. The results of this research are the position of PPK in government procurement contracts of goods/services starting from determining the contract design, controlling the contract and contract completion. So that the PPK is also responsible for the charges if something goes wrong. PPK's personal responsibility in the procurement of government goods/ services is personal responsibility that arises from the PPK's maladministration in the use of authority as an executing officer and the maladministration act creates criminal responsibility. Meanwhile, the responsibility of the PPK position in the procurement of government goods/services is the responsibility of legality (legality) of the use of authority in procurement by PPK which rests on the authority, procedure and substance, and creates accountability for the government/state.

Keywords: Responsibility; Committing Officer (PPK); Deviations Procurement of Government Goods/ Services 


\section{PENDAHULUAN}

Banyaknya penyimpangan dalam proses pengadaan barang/jasa Pemerintah, terjadi karena perbuatan pejabat pengadaan yang melakukan penyalahgunaan wewenang yang dimiliki oleh pejabat tersebut. Penyimpangan tersebut menimbulkan kerugian keuangan negara, sehingga hal ini memenuhi unsur-unsur yang termaktub di dalam delik korupsi. Apabila meninjau dari segi pertanggungjawaban, dalam praktiknya di lapangan, pertanggungjawaban atas penyimpangan terhadap suatu proses pengadaan barang dan jasa Pemerintah dilimpahkan sepenuhnya terhadap Pejabat Pembuat Komitmen atau PPK, hal ini sebagaimana tersirat dalam ketentuan Peraturan Presiden mengenai Pengadaan Barang/Jasa.

Hal ini menimbulkan rasa ketidakadilan, mengingat bahwa berdasarkan Peraturan Presiden Nomor 16 Tahun 2018 tentang Pengadaan Barang/ Jasa Pemerintah, nampak terlihat bahwa dalam proses pelaksanaan pengadaan barang/jasa tidak hanya PPK yang terlibat, tetapi terdapat pihakpihak lainnya yang turut mengambil peran dalam pengadaan barang dan jasa yang saling terkait satu sama lain, diantaranya adalah Pengguna Anggaran dan Kuasa Pengguna Anggaran. Dimana PA memiliki tugas dan kewenangan dalam menerapkan Rencana Umum Pengadaan sedangkan KPA memiliki kewenangan sesuai dengan apa yang dilimpahkan oleh PA mengenai pengadaan.

Terdapat beberapa contoh putusan terkait tindak pidana korupsi dalam pengadaan barang/jasa yang melibatkan Pejabat Pembuat Komitmen (PPK) sebagai pelaku tindak pidana, sebgaimana berikut:

1. Pertama, Putusan No. 457 K/Pid.Sus/2012, Terdakwa atas nama Ir. Edy Karyoso, MM selaku PPK untuk pengadaan pekerjaan peningkatan Jalan Gubug Jekerto Kabupaten Grobongan TA 2008.

2. Kedua, Putusan No. 1287 K/Pid.Sus/2013, Terdakwa atas nama Prof. Dr. H. Abdus Salam, Dz, MM. selaku PPK untuk kegiatan pengadaan alat-alat komunikasi dan teknologi informasi pada IAAN Syekh Nurjati Cirebon.

3. Ketiga, Putusan No. 2543 K/Pid.Sus/2013, Terdakwa atas nama Sutanto, S.T., M.T. selaku PPK untuk pengadaan pekerjaan normalisasi Sungai Gawe yang berlokasi di 4 desa yaitu Desa
Pekunden, Desa Kedunggede, Desa Kejawar, dan Desa Sudagaran Kecamatan Banyumas Kabupaten Banyumas.

4. Keempat, Putusan No. 99/Pid.Sus/TPK/2014/ PN.Sby, Terdakwa atas nama Agus Kuncoro, S.Sos. selaku PPK untuk proyek pembangunan gedung Kanwil DJBC Jatim I (lanjutan) Surabaya TA 2012 terletak di Jalan Raya Juanda Km. 3-4 Semambung Kecamatan Gedang Kebupaten Sidoarjo.

Apabila meninjau dari segi pertanggungjawaban, dalam praktiknya di lapangan, pertanggungjawaban atas penyimpangan terhadap suatu proses pengadaan barang dan jasa Pemerintah dilimpahkan sepenuhnya terhadap Pejabat Pembuat Komitmen atau PPK, hal ini sebagaimana tersirat dalam ketentuan Peraturan Presiden mengenai Pengadaan Barang/Jasa.

Hal ini menimbulkan rasa ketidakadilan, mengingat bahwa berdasarkan Peraturan Presiden Nomor 16 Tahun 2018 tentang Pengadaan Barang/ Jasa Pemerintah, nampak terlihat bahwa dalam proses pelaksanaan pengadaan barang/jasa tidak hanya PPK yang terlibat, tetapi terdapat pihak-pihak lainnya yang turut mengambil peran dalam pengadaan barang dan jasa yang saling terkait satu sama lain, diantaranya adalah Pengguna Anggaran dan Kuasa Pengguna Anggaran. Dimana PA memiliki tugas dan kewenangan dalam menerapkan Rencana Umum Pengadaan sedangkan KPA memiliki kewenangan sesuai dengan apa yang dilimpahkan oleh PA.

\section{PERUMUSAN MASALAH}

Berdasarkan uraian di atas, maka dapat ditarik suatu rumusan permasalahan sebagai berikut Kedudukan dan tanggung jawab Pejabat Pembuat Komitmen (PPK) dalam kontrak pengadaan barang/ jasa pemerintah.

\section{METODE PENELITIAN}

Metode penelitian yang akan dipergunakan adalah yuridis normatif. Dalam pembahasannya, penelitian ini menggunakan pendekatan perundangundangan (statute approach), pendekatan kasus (case approach) dan juga pendekatan konseptual (conceptual approach). ${ }^{1}$

\footnotetext{
${ }^{1}$ Peter Mahmud Marzuki. (2005). Penelitian Hukum.
} Jakarta: Kencana, h. 93. 


\section{PEMBAHASAN}

Pemerintah mempunyai kewajiban menyediakan kebutuhan rakyat dalam berbagai bentuk, baik yang berupa barang dan jasa maupun pembangunan infrastruktur. Di satu sisi, pemerintah sebagai penyelenggara pemerintahan juga memerlukan barang atau jasa itu dalam melaksanakan kegiatan pemerintah. Dengan demikian, pemenuhan kebutuhan barang dan jasa merupakan bagian yang penting dalam penyelenggaraan pemerintahan. ${ }^{2}$

Pada saat ini, pengadaan barang tidak terbatas pada barang yang berwujud tetapi juga barang yang tidak berwujud. Barang yang tidak berwujud seperti jasa pelayanan kesehatan, jasa pelayanan pendidikan, jasa konsultasi, jasa supervise, jasa manajemen dan lain-lainnya. Pengadaan barang tak berwujud tersebut merupakan asal usul pengadaan jasa konsultansi dan jasa lainnya. ${ }^{3}$ Sehingga atas pengadaan tersebut, wajib dilakukan sebuah perjanjian antara Pemerintah Daerah dengan Pihak Swasta dimungkinkan sepanjang menyangkut Public Services. ${ }^{4}$

Kegiatan Pengadaan Barang/Jasa oleh Pemerintah mempunyai sejarah yang panjang sejak berlakunya aturan khusus tentang Pengadaan Barang/ Jasa Pemerintah pada tahun 2003. Ada beberapa hal penting yang diatur di dalam Keppres tersebut yakni diantaranya adalah pengadaan barang/jasa seluruhnya dibiayai dari pinjaman/hibah luar negeri (PHLN) dan pengadaan barang/jasa untuk investasi di lingkungan BI, BHMN, BUMN, BUMD, yang pembiayaannya sebagian atau seluruhnya dibebankan pada APBN/APBD. Berbeda dengan instrumen hukum setelahnya, Keppres ini tidak mengatur secara tegas dan terperinci keberadaan PPK dalam suatu proses Pengadaan. Namun, kewenangan dan fungsinya telah diakomodir oleh kepala kantor/satuan kerja sebagaimana diatur di dalam Pasal 1 angka 4 Keppres ini. Meskipun mempunyai nomenklatur yang berbeda terhadap orang yang bertanggungjawab langsung.

\footnotetext{
${ }^{2}$ Y. Sogar Simamora. (2013). Hukum Kontrak-Kontrak Pengadaan Barang dan Jasa Pemerintah di Indonesia. Surabaya: Kantor Hukum "WINS \& Partners Law Firm" bekerjasama dengan Laksbang Justitia Surabaya, Edisi Kedua, Maret, h. 1.

${ }^{3}$ Adrian Sutedi. (2012). Aspek Hukum Pengadaan Barang \& Jasa. Jakarta: Sinar Grafika, h. 3.

${ }^{4}$ Arsyad Nurdjaman. (1992). Keuangan Negara. Jakarta: Intermedia, h. 17.
}

Perpres 16 Tahun 2018 yang diterbitkan pada 22 Maret 2018 mengatur banyak hal tentang kebijakan Pengadaan Barang/Jasa. Hal ini dimaksudkan untuk menyempurnakan Keppres nomor 80 tahun 2003 yang menurut penulis kurang memuat beberapa hal diantaranya keberadaan subjek hukum dalam proses pengadaan Barang/Jasa itu sendiri. Di dalam perpres ini terdapat beberapa subjek diantaranya PPK, Pemerintah, K/L/D/I (Kementerian/Lembaga/Satuan Kerja Perangkat Daerah/Institusi lainnya), LKPP, PA, KPA, dan lain sebagainya. Selain itu, Perpres ini juga pernah mengalami beberapa kali perubahan yang berarti terus-menerus diupayakan perbaikan guna mewujudkan proses Pengadaan Barang/Jasa.

Pada proses Pengadaan Barang/Jasa Pemerintah terdapat beberapa pihak yang berperan baik yang terlibat langsung maupun tak langsung yakni diantaranya PA/KPA, PPK, Pejabat Pengadaan dan Panitia/Pejabat Penerima Hasil Pekerjaan. Salah satu pihak yang memegang peran fundamental adalah Pejabat Pembuat Komitmen atau yang biasa dikenal dengan PPK. Secara Yuridis, PPK mempunyai beberapa tugas pokok dan kewenangan yang diamanatkan oleh Hukum, dari awal penyusunan perencanaan pengadaan sampai dengan menyimpan dan menjaga keutuhan seluruh dokumen pelaksanaan kegiatan serta menilai kinerja Penyedia. PPK dilarang mengadakan ikatan perjanjian atau menandatangani Kontrak dengan Penyedia, dalam hal belum tersedia anggaran belanja atau tidak cukup tersedia anggaran belanja yang dapat mengakibatkan dilampauinya batas anggaran belanja yang tersedia untukkegiatan yang dibiayai APBN/APBD.

Keberadaan PPK dalam suatu Pengadaan Barang/ Jasa memang ada karena jabatan dalam suatu struktur kelembagaan di suatu instansi Pemerintahan. Namun, PPK adalah orang yang dipilih oleh atasannya yang dalam hal ini ialah PA/KPA. Hal ini diatur tegas di dalam Peraturan Presiden tentang Pengadaan Barang/ Jasa Pemerintah. Adapun bunyi dari ketentuan ini yaitu:

"PPK merupakan Pejabat yang ditetapkan oleh PA/ KPA untuk melaksanakan Pengadaan Barang/ Jasa". Keberadaan PPK berfungsi untuk melakukan Pengadaan Barang/Jasa saja, tidak diperuntukkan untuk melakukan kegiatan selain ini dan biasanya apabila segala hal tentang Pengadaan Barang/Jasa telah selesai maka ia dibebastugaskan sepanjang 
Naony Fenti Istiglallia, Raissa Ardelia, dan Pramudya Ramadhanti,

tidak ada pelanggaran atau penyimpangan terhadap hukum yang berlaku. Orang yang dapat ditunjuk sebagai PPK bukanlah orang sembarangan apalagi serta merta ditunjuk tanpa pertimbangan, namun haruslah orang yang sesuai dengan tugas yang diembannya. Oleh karena itu, seseorang yang dapat ditunjuk sebagai PPK haruslah mempunyai kriteria tersendiri. Sehingga ada syarat minimum agar seseorang dapat melaksanakan beberapa fungsi yang sebagaimana kita tahun melibatkan uang negara. Oleh sebabnya, posisi dan jabatan PPK tidak dapat dipaksakan karena memang kewajiban yang cukup berisiko. Peran PPK setelah kontrak ditandatangani dengan penyedia adalah mengelola kontrak sehingga kontrak dapat mencapai tujuannya.

Sering kita mengabaikan kontrak, karena nanti akan ada solusi bila pekerjaan sampai masa waktu kontrak belum mencapai target, masih dapat ada pertimbangan untuk perpanjangan waktu penyelesaian pekerjaan. Seharusnya kita berpikir seolah-olah tidak ada waktu kesempatan perpanjangan waktu. ${ }^{5}$ PPK yang merupakan organ penting dalam proses Pengadaan tidak hanya bekerja keras saat periode pra-kontrak saja, karena ia juga wajib menjaga stabilnya pengadaan saat dalam proses pengerjaan. Hal ini dimaksudkan karena suatu proyek pemerintah adalah untuk kemaslahatan umat yang manfaatnya nanti akan dinikmati orang banyak selain sumber pendanaannya berasal dari uang Negara. Dalam menjaga kestabilan pekerjaan saat Pengadaan, PPK dapat melakukan beberapa pekerjaan setelah kontrak ditandatangani yakni diantaranya: ${ }^{36}$

(1) Identifikasi tujuan capaian kontrak yang dapat dilihat dalam kontrak atau spesifikasi, gambar dan dokumen lain yang dibuat konsultan perencana atau tenaga ahli.

(2) Membuat tim untuk administrasi pelaksanaan kontrak dan pengawasan kontrak.

(3) Membuat alat pengendalian pekerjaan, yang sering disebut dengan kurva $\mathrm{S}$ atau membuat pengendalian misal dalam bentuk sederhana.

PPK yang mempunyai tugas sangat kompleks sejatinya juga pejabat pemerintah pada umumnya yang juga mempunyai peran konstan di dalam suatu instansi tertentu. Hal ini berarti proses Pengadaan

\footnotetext{
5 Mudjisantoso. (2014). Memahami Kontrak Pengadaan Pemerintah Indonesia. Yogyakarta: Primaprint, h. 40.

6 ibid., h. 41 .
}

bukanlah satu-satunya pekerjaan yang PPK tangani sehingga membutuhkan supported team yang dapat mem-back up fungsinya. Supported team yang dimaksud untuk membatu PPK dalam melaksanakan tugasnya adalah Pengelola Pengadaan Barang/Jasa. Kontrak Pengadaan Barang/Jasa yang selanjutnya disebut Kontrak adalah perjanjian tertulis antara PPK dengan Penyedia Barang/Jasa atau pelaksana Swakelola. Dalam melaksanakan kontrak pekerjaan konstruksi, PPK dapat dibantu pegawai yang berperan Direksi lapangan atau direksi teknis.

Direksi lapangan adalah tim pendukung yang dibentuk/ditetapkan oleh PPK, terdiri dari 1 (satu) orang atau lebih, yang ditentukan dalam syarat-syarat khusus kontrak untuk mengendalikan pelaksanaan pekerjaan. Sedangkan Direksi teknis adalah tim pendukung yang ditunjuk/ditetapkan oleh PPK untuk mengawasi pelaksanaan pekerjaan. Dalam PPK tidak memiliki kompetensi dalam aspek teknis, misalnya dalam pekerjaan kontruksi maka dapat membentuk tim teknis. Tim teknis untuk pekerjaan konstruksi dapat berasal dari Dinas PU/Kementrian PU atau tenaga ahli dari Fakultas Teknik Perguruan Tinggi. ${ }^{7}$

Terkait keterlibatan PPK di dalam kontrak pengadaan, sebagaimana kita ketahui bahwa PPK adalah pihak yang terlibat langsung di dalam penandatanganan kontrak. Akibat hukum bagi pihak yang terlibat di dalam kontrak sebagaimana diatur di dalam Pasal 1338 KUHPerdata dan juga Azas Pacta Sunt Servanda yakni keberlakuan perjanjian adalah sama dengan undang-undang bagi pihaknya. Oleh sebab itulah penting untuk memahami jenis dan bentuk kontrak yang akan dibuat oleh para pihak

Kedudukan Pejabat Pembuat Komitmen (PPK) pada proses Pengadaan Barang/Jasa Pemerintah berdasarkan Pasal 1 angka 10 Perpres Pengadaan Barang/Jasa Pemerintah, Pejabat Pembuat Komitmen yang selanjutnya disebut PPK adalah pejabat yang diberi kewenangan oleh PA/KPA untuk mengambil keputusan dan/atau melakukan tindakan yang dapat mengakibatkan pengeluaran dengan maladministrasi dalam penggunaan wewenang maupun public service.

Pertanggungjawaban atau yang dikenal dengan konsep liability dalam segi falsafah hukum, seorang filosof besar abad ke 20, Roscoe Pound menyatakan bahwa: I...Use simple word "liability" for the situation whereby one may exact legally and other is

\footnotetext{
${ }^{7}$ Ibid., h. 174.
} 
legally subjeced to the exaction". Pertangungjawaban pidana diartikan Pound adalah sebagai suatu kewajiban untuk membayar pembalasan yang akan diterima pelaku dari seseorang yang telah di rugikan, menurutnya juga bahwa pertanggungjawaban yang dilakukan tersebut tidak hanya menyangkut masalah hukum semata akan tetapi menyangkut pula masalah nilai-nilai moral ataupun kesusilaan yang ada dalam suatu masyarakat. ${ }^{8}$

Pertanggungjawaban pidana dalam bahasa asing di sebut sebagai toereken-baarheid, criminal reponsibilt, criminal liability, pertanggungjawaban pidana disini dimaksudkan untuk menentukan apakah seseorang tersebut dapat di pertanggungjawabkan atasnya pidana atau tidak terhadap tindakan yang di lakukanya itu. ${ }^{9}$

Permasalahan yang terjadi dalam proses pengadaan barang/jasa Pemerintah tersebut, sering terjadi dikarenakan adanya perbuatan pejabat pengadaan serta pejabat terkait lainnya yang melakukan penyalahgunaan wewenang yang dimiliki oleh pejabat tersebut. Penyimpangan yang dilakukan tersebut menimbulkan kerugian terhadap keuangan negara, hal ini dikarenakan mengingat bahwa sumber dana pengadaan barang dan jasa Pemerintah berasal dari keuangan negara yang tercantum dalam APBN/ APBD, sehingga hal ini memenuhi unsur-unsur yang termaktub di dalam delik korupsi. Apabila meninjau dari segi pertanggungjawaban, dalam praktiknya di lapangan, pertanggungjawaban atas penyimpangan terhadap suatu proses pengadaan barang dan jasa Pemerintah dilimpahkan sepenuhnya terhadap Pejabat Pembuat Komitmen atau PPK, hal ini sebagaimana tersirat dalam ketentuan Peraturan Presiden mengenai Pengadaan Barang/Jasa.

Hal ini menimbulkan rasa ketidak adilan, mengingat bahwa berdasarkan Peraturan Presiden Nomor 16 Tahun 2018 tentang Pengadaan Barang/ Jasa Pemerintah, nampak terlihat bahwa dalam proses pelaksanaan pengadaan barang/jasa tidak hanya PPK yang terlibat, tetapi terdapat pihak-pihak lainnya yang turut mengambil peran dalam pengadaan barang dan jasa yang saling terkait satu sama lain,

${ }^{8}$ Roscoe Pound. (2000). "Introduction to The Phlisophy of Law" dalam Romli Atmasasmita, Perbandingan Hukum Pidana. Cet. II. Bandung: Mandar Maju, h. 65.

${ }^{9}$ S.R. Sianturi. (1996). Asas-asas Pidana di Indonesia dan Penerapannya. Jakarta: Alumni Ahaem-Petehaem, h. 245. diantaranya adalah Pengguna Anggarandan Kuasa Pengguna Anggaran. Dimana PA memiliki tugas dan kewenangan dalam menerapkan Rencana Umum Pengadaan sedangkan KPA memiliki kewenangan sesuai dengan apa yang dilimpahkan oleh PA mengenai pengadaan barang dan jasa Pemerintah.

Dari kedua penjelasan tugas dan kewenangan tersebut, nampak terlihat bahwa dalam suatu proses pengadaan barang dan jasa pemerintah, tidak hanya melibatkan PPK sebagai pemegang peran utama dalam pengadaan barang dan jasa Pemerintah, namun ada lembaga-lembaga lain yang juga terkait dalam proses pelaksanaan pengadaan barang dan jasa Pemerintah, diantaranya PA atau Pengguna Anggaran dan KPA atau Kuasa Pengguna Anggaran. Sehingga tidak adil apabila dalam hal pertanggungjawaban atas penyelewengan pelaksanaan pengadaan barang dan jasa pemerintah sepenuhnya ditanggung oleh PPK atau Pejabat Pembuat Komitmen. Hampir semua penyelesaian kasus tindak pidana korupsi dalam pengadaan barang/jasa pemerintah didasarkan atas pendekatan normatif. Tingkat kedalaman dalam penelususran kesalahan dan korelasinya dengan kesengajaan semata-mata didasarkan atas teori pengetahuan dan kehendak

Kedudukan hukum Pejabat Pembuat Komitmen (PPK) sebagai tolak ukur/acuan pertanggungajawaban hukum dalam menentukan seajuah mana PPK dapat dimintakan pertanggungjawaban pidana dalam permasalahan penyimpangan pengadaan barang/jasa pemerintah. Hal ini selasar dan relevan dengan prinsip keadilan berdasarkan Pasal 6 Peraturan Presiden Nomor 16 Tahun 2018 tentang Pengadaan Barang/ Jasa Pemerintah. Dengan demikian, menimbulkan rasa adilan, mengingat bahwa berdasarkan Peraturan Presiden Nomor 16 Tahun 2018 tentang Pengadaan Barang/Jasa Pemerintah, nampak terlihat bahwa dalam proses pelaksanaan pengadaan barang/jasa tidak hanya PPK yang terlibat, tetapi terdapat pihakpihak lainnya yang turut mengambil peran dalam pengadaan barang dan jasa yang saling terkait satu sama lain.

\section{PENUTUP}

\section{Kesimpulan}

Kedudukan Pejabat Pembuat Komitmen (PPK) dalam kontrak pengadaan barang/jasa pemerintah dimulai dari menetapkan rancangan 
kontrak, mengendalikan Kontrak dan penyelesaian Kontrak. Sehingga Pejabat Pembuat Komitmen (PPK) membutuhkan banyak pemahaman dan atau kemampuan dalam kontrak pengadaan barang/ jasa pemerintah, dimana berhasil dan tidaknya proses pengadaan barang dan jasa menuntut suatu keahlian dan ketelitian serta tanggung jawab dari pejabat pengadaan, apabila terjadi kesalahan dalam pelaksanaannya yang menimbulkan kerugian negara yang berujung pada tuntutan ganti rugi atau tuntutan lainnya. Tanggungjawab pribadi Pejabat Pembuat Komitmen (PPK) dalam pengadaan barang/jasa pemerintah adalah tanggungjawab pribadi yang timbul atas tindakan maladministrasi PPK dalam penggunaan wewenang sebagai pejabat pelaksana dan tindakan maladministrasi tersebut melahirkan tanggungjawab pidana. Sedangkan tanggungjawab jabatan Pejabat Pembuat Komitmen (PPK) dalam pengadaan barang/jasa pemerintah adalah tanggungjawab keabsahan (legalitas) penggunaan wewenang dalam pengadaan oleh PPK yang bertumpu pada wewenang, prosedur dan substansi. Tanggungjawab jabatan melahirkan tanggung gugat pemerintah/negara.

\section{Rekomendasi}

Diperlukan untuk memasukan konsep kedudukan Pejabat Pembuat Komitmen (PPK) secara jelas dan tegas ke dalam revisi Peraturan Presiden Nomor 16 Tahun 2018 tentang Pengadaan Barang/Jasa Pemerintah, dimana kedudukan Pejabat Pembuat Komitmen (PPK) selaku bawahan dari Pengguna Anggaran (PA)/Kuasa Pengguna Anggaran (KPA). Diperlukan adanya pengaturan yang lebih baik lagi terkait pengadaan barang/jasa pemerintah, dimana tidak hanya diatur dalam bentuk Peraturan Presiden, namun perlu diatur dalam bentuk Undang-Undang khusus terkait pengadaan barang/jasa pemerintah, oleh karena itu harus disusun RUU tentang pengadaan tersebut.

\section{DAFTAR PUSTAKA}

\section{Peraturan Perundang-Undangan:}

Peraturan Presiden Nomor 16 Tahun 2018 tentang Pengadaan Barang/Jasa Pemerintah.

Keputusan Presiden Nomor 80 Tahun 2003 tentang Pedoman Pelaksanaan Pengadaan Barang/ Jasa Pemerintah.

\section{Buku:}

Adrian Sutedi. (2012). Aspek Hukum Pengadaan Barang \& Jasa. Jakarta: Sinar Grafika.

Arsyad Nurdjaman. (1992). Keuangan Negara. Jakarta: Intermedia.

Mudjisantoso. (2014). Memahami Kontrak Pengadaan Pemerintah Indonesia. Yogyakarta: Primaprint.

Peter Mahmud Marzuki. (2005). Penelitian Hukum. Jakarta: Kencana.

Roscoe Pound. (2000). "Introduction to The Phlisophy of Law" dalam Romli Atmasasmita, Perbandingan Hukum Pidana. Cet. II. Bandung: Mandar Maju.

S.R. Sianturi. (1996). Asas-asas Pidana di Indonesia dan Penerapannya. Jakarta: Alumni AhaemPetehaem.

Y. Sogar Simamora. (2013). Hukum Kontrak-Kontrak Pengadaan Barang dan Jasa Pemerintah di Indonesia. Surabaya: Kantor Hukum "WINS \& Partners Law Firm" bekerjasama dengan Laksbang Justitia Surabaya, Edisi Kedua, Maret. 